\title{
DUYGUSAL ZEKA VE ÖRGÜTSEL VATANDAŞLIK DAVRANIŞI İLIŞKISİ
}

\section{Zübeyir BA $\breve{G} C I^{*}$}

Atıf/O: Bağcl, Zübeyir, (2014). "DuygusalZekâ ve Örgütsel Vatandaşlık Davranışı İlişkisi”, Hitit Üniversitesi Sosyal Bilimler Enstitüsü Dergisi, Yıl 7, Sayı 2, ss. 259-279.

Özet: Bu çalışmanın amacı, Duygusal Zeka ile Örgütsel Vatandaşlık Davranışı arasındaki ilişkiyi Araştırmaktır. Bu amaçla, bankacılık sektöründe çalışan 210 katılımcı üzerinde survey yöntemine dayalı bir alan araştırması yürütülmüştür. Verileri toplamak için bu çalışmada iki standart ölçek kullanılmıştır: Wong ve Law (2002) tarafindan geliştirilen Duygusal Zeka Ölçeği ve Basım ve Şeşen (2006) tarafindan geliştirilen Örgütsel Vatandaşlık Davranışı Ölçeği. İki değişken seti arasındaki ilişkinin araştırılmasında Kanonik Korelasyon Analizi uygulanmıştır. Araştırma sonuçlarına göre; çalışanların Duygusal Zekalarının onların Örgütsel Vatandaşlık Davranışlarındaki varyansın \%14'ünü açıkladığı tespit edilmiştir; DZ değişkenleri ile ÖVD değişkenleri arasında anlamlı ilişki bulunmuştur.

Anahtar Kelimeler: Duygusal Zeka, Örgütsel Vatandaşlık Davranışı, Kanonik Korelasyon 


\section{The Relationship Between Emotional Intelligence And Organizational Citizenship Behavior}

Citation/@: Bağcl, Zübeyir (2014). "The Relationship Between Emotional Intelligence And Organizational Citizenship Behavior", Hitit University Journal of Social Sciences Institute, Year 7, Issue 2, pp. 259-279.

Abstract: The aim of present study is to investigate the relationship between the Emotional Intelligence and Organizational Citizenship Behavior. For this aim, a field research based on survey method was conducted on 210 banking sector employees. To collect data, present study used two standardized questionnaires: Emotional Intelligence Questionnaire developed by Wong and Law (2002) and Organizational Citizenship Behavior Questionnaire developed by Basim and Şeşen (2006). Canonical correlation analysis has been applied to investigate the relationship between the two sets of variables. As a result of the research; it was determined that the employees' Emotional Intelligence explain 14\% of the variance in their Organizational Citizenship Behaviors; significant relationship was found between Emotional Intelligence dimensions and Organizational Citizenship Behavior dimensions.

Keywords: Emotional Intelligence, Organizational Citizenship Behavior, Canonical Correlation

\section{GİRIŞ}

Günümüzde örgütlerde ortaya çıkan birçok problemin temelinde yatan faktör çalışanların teknik bilgi düzeylerindeki yetersizlikleri veya zeka ile ilgili yeteneklerinin eksikliği değil daha çok sahip oldukları duyguları anlayabilme, başkalarına aktarabilme ve yönetebilme ile ilgili yetenek ve becerilerindeki eksiklikleridir (Acar, 2002: 54).

Goleman (1998) duyguları, bireylerin öğrenme potansiyellerini geliştiren; bilinmeyene ilişkin merakını giderme adına soru sormaya ve araştırma yapmaya yönelten, elde ettiği bilgiyi somut hale getirmek suretiyle davranışlarını şekillendiren özellikler bütünü olarak nitelendirmektedir (Akt; Ural, 2001: 210). Örgüt içerisinde meydana gelen çeşitli olaylar çalışanların duygularını harekete geçirerek çeşitli duygusal tepkiler vermelerine neden olmaktadır. Bu tepkiler genellikle anlık tepkiler şeklinde ortaya çıkmaktadır. Ancak çalışanın olumlu ya da olumsuz duygusallık yaşama eğilimi her karşılaşılan olaya vereceği tepkinin türü ve şiddetini etkileyebilecektir. Söz konusu bu duygusal tepkiler zaman içerisinde birikmek suretiyle çalışanın kendi iradesiyle, gönüllü olarak ortaya koyduğu, biçimsel olarak tanımlanmamış ama örgütün 
işleyişine olumlu katkılar sağlayan davranışlar olarak nitelendirilen örgütsel vatandaşlık davranışlarını etkilemektedir (Karakuş, 2008: 55). Çalışanların sergiledikleri örgütsel vatandaşlık davranışları ise örgütün genel anlamdaki performansını ve başarısını arttırmaktadır. Dolayısıyla klasik yönetim anlayışının bir uzantısı olarak duyguları örgüt yaşamından soyutlayarak tamamen rasyonel ilkeler çerçevesinde hareket etmenin örgütlerin etkinliği ve başarısı için yeterli olabileceği düşüncesi geçerliliğini yitirmiştir.

$\mathrm{Bu}$ çalışmanın amacı çalışanların duygusal zekaları ile örgütsel vatandaşlık davranışları arasındaki ilişkiyi incelemektir. Gerek duygusal zeka gerekse de örgütsel vatandaşlık davranışına ilişkin birçok ampirik araştırma yapılmış ve bunların birçok faktörle olan ilişkisi incelenmiş olmakla birlikte duygusal zekanın alt boyutları ile örgütsel vatandaşlık davranışının alt boyutları arasındaki ilişkiyi inceleyen çok az sayıda araştırma bulunmaktadır. Bununla birlikte bu iki değişken arasındaki ilişkiyi kanonik korelasyon analizi kullanarak inceleyen çalışmaya henüz rastlanılmamış olması da bu çalışmanın hazırlanmasında etkili olan nedenlerden birisini oluşturmaktadır.

\section{DUYGUSAL ZEKA}

Duygusal zeka kavramı ilk kez Wayne Payne (1986) tarafından ortaya atılmakla birlikte yazında kullanılmaya başlanması Salovey ve Mayer'in (1990) çalışmaları sonucunda olmuştur (Çapraz vd., 2009:195). Kavramın yaygınlaşmasını ve akademik çevrelerin dışına yayılmasını sağlayan ise Daniel Goleman'ın (1995) yazmış olduğu "Duygusal Zeka Neden IQ’dan Önemlidir" isimli kitabıdır (Çakar ve Arbak, 2004: 34).

İlgili yazın incelendiğinde duygusal zekanın tanımıyla ilgili olarak Cobb ve Mayer (2000) tarafından dile getirilen iki farklı yaklaşım göze çarpmaktadır. Bunlardan ilki; duygusal zekanın doğuştan getirilen yeteneklerden kaynaklandığını öne süren yetenek modelidir. Bu modelde duygusal zeka, Salovey ve Mayer (1990) tarafından, "kişinin hem kendisinin hem de başkalarının hislerini ve duygularını tanıyabilme, bunlar arasında ayrım yapabilme ve bu bilgileri kullanarak düşünce ve faaliyetlerine rehberlik edebilme yeteneğini içeren bir set" olarak tanımlanmaktadır. Bu model yeteneğe dayalı olmayan faktörlerin önemini kabul etmekle beraber bunların duygusal zekadan bağımsız olduklarını varsaymaktadır.

Diğeri ise duygusal zeka ile ilgili becerilerin sonradan geliştirilebileceğini öne süren karma modeldir. Bu modelde duygusal zeka, Goleman (1995) tarafından, "kişinin kendisini ve diğerlerini yönetebilmesini sağlayacak yeteneklerinin oluşturduğu karmaşık bir set” olarak tanımlanmaktadır (Akt; 
Ahmad, Bangashs ve Khan, 2009: 127). Benzer bir tanım da Bar-on (1997) tarafından yapılmıştır. O'na göre duygusal zeka "kişinin çevresel taleplerin ve baskıların üstesinden gelme yeteneğini etkileyen bir dizi kişisel, duygusal ve sosyal yetkinlikler ve becerilerdir." (Weerdt ve Rossi, 2012: 145). Duygusal zeka anlamında ileri düzeyde olan çalışanlar kariyerlerinde daha başarılı olurken, çalışma ortamından kaynaklanan stresle daha kolay başa çıkabilmekte ve iş ortaminda bulunan diğer insanlarla daha doğru ve etkili ilişkiler kurabilmektedirler (Tokmak, Yıldız ve Turgut, 2013: 96-97). Sonuç itibariyle duygusal zeka, bireyin sosyal yaşamını ve çalışma hayatını tanıyabilmesi ve davranışları üzerinde etkili olan duygularını en iyi şekilde kontrol edebilme yeteneği biçiminde özetlenebilir (Gürbüz ve Yüksel, 2008: 176).

Duygusal zekanın sınıflandırılmasına ilişkin yazında genel kabul gören üç önemli model söz konusudur (Özdemir ve Özdemir, 2007: 394-395).

Bunlardan ilki duyguları başkalarına aktarabilmek ve idare edebilmek için kişinin sahip olması gereken bir dizi zihinsel yetenek üzerine odaklanan Salovey ve Mayer (1990) modelidir. Bu modele göre duygusal zeka, kendi duygularını algılama, doğru değerlendirme ve ifade edebilme, başkalarının duygularını anlama ve doğru değerlendirme, duyguları uygun biçimde kullanma ve duyguları kontrol etme olmak üzere birbiriyle ilişkili dört ana yetenekten oluşmaktadır. Bu yeteneklere sahip olan bireyler iyi uyumlu ve duygusal açıdan yetenekli kişiler olarak kabul edilirlerken; sahip olmayan kişiler duygusal ve sosyal işlevselliklerinde sorunlar yaşayabilirler (Mayer, DiPaolo ve Salovay, 1990: 772-773; Fiori ve Antonakis, 2011: 330; Hans, Mubeen ve Rabani, 2013: 360).

Bir diğeri duyguların bireylerin başarıları üzerindeki etkisine odaklanan Bar-on (1997) modelidir. Bu modelde duygusal zeka bireyin kendisini ve çevresindeki diğer insanları anlama, onlarla iyi ilişkiler kurabilme, ortaya çıkan beklenmedik olaylar karşısında çabuk uyum göstermek suretiyle sorunları bertaraf edebilme ve çevrenin baskılarına boyun eğmeden başarılı bir şekilde üstesinden gelebilme becerisi olarak ifade edilmektedir (Gürbüz ve Yüksel, 2008:177). Bar - On duygusal zekayı 15 alt boyuttan oluşan toplam 5 genel bölümde incelemektedir. Bunlar: kişisel yetenekler, bireyler arası beceriler, uyum, stres yönetimi ve genel ruh halidir (Fernandes-Berrocal ve Extremera, 2006: 9).

Bir başka duygusal zeka modeli de Goleman (1995) tarafından ileri sürülen ve kendi içinde 5 temel boyutu barındıran modeldir. Bu boyutlar şu şekilde sıralanabilir: duygularını anlama, duygularını idare etme, kendini motive etme, başkalarının duygularını tanıma ve ilişkileri yönetme (Akt; Cingisiz ve Murat, 2010:101). 
Bu çalışmada Salovey ve Mayer (1990) modeli benimsenmiştir. Modelde geçen yetenekler şu şekilde özetlenebilir (Wong ve Law, 2002: 246):

Duyguları algılama: Bireyin sahip olduğu duygularını, yaşadığı ruh halini ve içinde bulunduğu durum ve şartların sebeplerini anlayabilme becerisini ifade etmektedir (Sudak ve Zehir, 2013:147). İçinde bulunduğu durum karşısında ne hissedeceğinin bilincinde olması sayesinde duygularının davranışlarına ne şekilde yansıyacağını tahmin edebilen birey rahatlıkla karşı taraf yerine kendini koyabilir.

Başkalarının duygularını anlama: $\mathrm{Bu}$ yetenek kişinin çevresindeki insanların duygularını algılaması ve anlamasıyla ilgilidir. Bu yeteneği yüksek olan kişiler çevresinde yer alan kişi veya kişilerin davranışlarından ne hissettiklerini anlayabilir, duygularını gözlemleyebilir ve onların duygularına karşı duyarlı bir şekilde yaklaşabilirler (Orhan, 2012: 14).

Duyguları kullanma: Bu kişilerin duygularını yararlı faaliyetler ve kişisel performansa yönlendirmek suretiyle belli bir alana yönlendirebilme yeteneğiyle ilgilidir (Maini, Singh ve Kaur, 2012:188).

Duyguları (kontrol etme) düzenleme: Bu yetenek, yaşanılan psikolojik sıkıntılardan hızlı bir biçimde kurtulabilmeyi sağlayacak şekilde duyguların kontrol edilebilmesiyle ilgilidir. Başka bir ifade ile kişinin duygularını kontrol altında tutmak suretiyle güvenilir ve tutarlı hareket etmesi ve yaşamda meydana gelen değişimlere kolay uyum sağlayabilmesidir (Girgin, 2009: 2). Bu yeteneği yüksek olan bireyeler hem kendilerinin hem de başkalarının yaşadığı olumsuz hislerin neden olabileceği istenmeyen sonuçların ortaya çıkmasını engelleyecek olumlu duygusal stratejiler geliştirebilirler.

\section{III. ÖRGÜTSEL VATANDAŞLIK DAVRANIŞI (ÖVD)}

ÖVD, örgütün sosyal ve psikolojik çevresine katkıda bulunarak hedeflerine ulaşmasına destek sağlayan gönüllülük temeline dayalı bireysel davranışlardır (Lievens ve Anseel, 2004: 299). Bu davranışlar örgütlerin biçimsel ödüllendirme sistemleri içerisinde doğrudan ve tam olarak dikkate alınmamakla birlikte, genel olarak değerlendirildiğinde örgütün fonksiyonlarının etkin bir biçimde yerine getirilmesine fayda sağlarlar (Yücel ve Samancı, 2009: 114). Çeşitli sebepler ile işe gelemeyen mesai arkadaşlarına yardım etme, kendi iş tanımları içerisinde olmasa dahi örgütün amaçları ve hedefleri için önem arz eden işleri gönüllü olarak üstlenmek, işe yeni başlayan arkadaşlarının sosyalleşmelerini kolaylaştırmak ve karşılaşacakları problemlerin üstesinden gelmelerine yardımcı olmak, yöneticilerin işlerini kolaylaştırmak, örgüt için 
yenilikçi öneriler geliştirmek suretiyle katma değer oluşturmak, olmas1 gerekenden daha fazla işe katılım göstermek, işe zamanında gelmek ve geçerli bir sebep olmadığı sürece devamsızlık yapmamak gibi davranışlar örgütsel vatandaşlık davranışına örnek olarak verilebilecek davranışlardır (Kelloway vd., 2002: 150; Sarı, 2011: 32). Bu tip davranışların hem çalışan hem de örgüt açısından oldukça büyük yararı vardır. Bununla birlikte örgütsel vatandaşlık davranışlarının; sadece örgüte pozitif katkısı olan davranışları değil aynı zamanda uygun olmayan durumlara karşı gösterilen hoşgörü, gönüllülük ve tahammül kalitesini de içerdiği söylenebilir.

ÖVD, her ne kadar örgütün biçimsel ödüllendirme sisteminin içerisinde yer almayan bir davranış biçimi olsa da, konu ile ilgili literatürde yapılan birçok ampirik çalışmaya dayanarak yöneticilerin çalışanlarının performanslarını değerlendirirken bu davranışları dikkate aldıkları görülmektedir (Özaslan, Acar ve Acar, 2009: 102).

ÖVD, Smith ve arkadaşları (1983) tarafından diğergamlık (başkalarına yardımcı olmaya yönelik davranışlar) ve genelleştirilmiş uyum (genel kurallara, normlara ve beklentiler ile uyum gösteren davranışlar) olarak iki boyutlu ele alınırken daha sonra Organ (1988) tarafından diğergamlık, sivil erdem, vicdanlılık, nezaket ve centilmenlik olmak üzere beş farklı boyutta ele alınmıştır (Chahal ve Mehta, 2011: 26). Bu çalışmada Organ (1988) tarafindan yapılan sınıflandırma kullanılacaktır. Bu sınıflamada yer alan boyutlar şu şekilde ifade edilebilir;

Diğergamlık: Diğergamlık ya da başka bir deyişle özgecilik, bireyi kendisi dışında diğer çalışanlara işleriyle ilgili konularda ihtiyaç duydukları zamanda tamamen gönüllü olarak ve her hangi bir karş1lk beklemeksizin isteğe bağlı ortaya koyduğu fayda sağlayıcı davranışları anlamına gelir (Atalay, 2009: 47). Geciken bir öğretmen arkadaşının öğrencileri ile ilgilenen eğitimcinin ya da hastaları zorda bırakmamak için işe gelemeyen hekim arkadaşı yerine hastalarıyla ilgilenen doktorun davranışları diğergamlığa/özgeciliğe örnek verilebilir.

Sivil erdem: Sivil erdem, örgütün menfaatlerini ön planda tutarak mesleki ve sosyal açıdan örgütün fonksiyonlarına destek verme, örgüte bağlanma konusunda gönüllü olmak ve örgütle yakından ilgilenme biçimindeki davranışları ifade eder (Sezgin, 2005: 323). Graham ve Van Dyne (2006), sivil erdem davranışının iki yönü olduğunu belirtmişlerdir. Bunlardan bilgi edinme yönü; örgüt içerisinde düzenlenen çeşitli toplantılara ve faaliyetlere katılma, haber bültenlerini ve ilanları okuma, örgüte yararı olabilecek diğer 
bilgi kaynaklarını da takip etme şeklindeki davranışları kapsamaktadır. Sivil erdem davranışının diğer yönünü ise olası sorunları veya iyileştirmeleri belirlemek amacıyla eleştirel düşünme yeteneklerini kullanma ve değişimleri gerçekleştirecek önerilerde bulunma gibi davranışları içeren egzersiz etkisi oluşturur (Graham ve Van Dyne, 2006: 92).

Vicdanlılık: Çalışanların kendilerine verilen görevleri yerine getirmek amacıyla üstlenmiş oldukları rollerine ilişkin sorumluluklarının ötesine geçmek suretiyle örgütün amaç ve faaliyetlerine yönelik gönüllü katkılarını ifade eder (Bolat ve Bolat, 2008, 79). Bu anlamda; işi aksatmamak ve gerektiğinde fazla mesai yapmak, zamanı en verimli biçimde kullanmak, dinlenme molalarında verilen sürelere azami ölçüde uymak, örgüt içerisindeki düzeni kurmaya ve devam ettirmeye yönelik oluşturulan kural ve kaidelere bağlı kalmak gibi davranışlar vicdanlılık için verilebilecek örneklerdir (Berberoğlu, 2013: 35).

Nezaket: Bir örgütte görevleri gereği birbirleriyle sürekli etkileşim içerisinde bulunan bireylerin yaptıkları iş ve alacakları kararlar itibariyle diğerlerinin işlerini olumsuz etkileyebilecek zararlardan sakınmalarını sağlamak amacıyla hatırlatma, uyarma ve danışma gibi davranışlar sergilemelerini ifade eder (Sezgin, 2005: 324). Nezakete dayalı davranışlar daha çok gelecek odaklıdır. Herhangi bir problem ortaya çıkmadan önce onun oluşumunu önlemeye yönelik çaba göstermek ya da problem ortaya çıktığı anda onun gelişimini hafifletmek amacıyla mümkün olan her türlü tedbiri almak bu davranışın kapsamı içerisinde yer almaktadır (Kaygısız, 20013: 76).

Centilmenlik: Örgütler her an için irili ufaklı pek çok sorunun ortaya çıkmasına elverişli ortamlardır. Çalışanların gerek kendilerinden gerekse iş ortamından kaynaklanan bu sorunları mümkün olduğunca büyütmemeleri, ortalığı velveleye vermek yerine sükûneti korumaya çalışmaları, vakitlerini sorunları dile getirerek geçirmek yerine ellerinden geldiğince çözüm önerileri geliştirmeye çalışmaları ve bu süreçte karşılaştıkları ufak hataları hoşgörüyle karşılayıp görmezlikten gelmeleri centilmenlik davranışlarına örnek oluşturmaktadır (Özaslan, Acar ve Acar, 2009: 103).

\section{DUYGUSAL ZEKA VE ÖRGÜTSEL VATANDAŞLIK DAVRANIŞI ARASINDAKI İLIŞKi}

İlgili yazında, yöneticilerin başarılarında yönetimsel becerilerinin ve duygusal zeka yeterliklerinin önemli bir etkiye sahip olduğu vurgulanmaktadır. Çalışanlarında olumlu duygular oluşturmayı başaran yöneticilerin, örgütsel vatandaşlık davranışları olarak adlandırılan başkalarına yardımcı olma, 
başkalarıyla işbirliği yapmak suretiyle yapıcı ilişkiler geliştirme ve karşılaşılan sorunlardan şikayet etmek yerine üstesinden gelmenin yollarını arama gibi davranışları daha fazla sergileyecekleri ifade edilmektedir (Karakuş, 2008: 64). Bu görüşü destekler nitelikte gerek yerli gerekse yabancı yazında yürütülmüş çeşitli araştırmalarda elde edilen bulgular aşağıda özetlenmiştir;

Korkmaz ve Arpacı (2009) tarafından çeşitli sanayi işletmelerinde çalışan yöneticiler ile onların astları üzerinde yürütülen çalışmada; yöneticilerin duygusal zekaları ile astlarının vicdanlılık, sivil erdem ve özgecilik davranışları arasında pozitif yönlü anlamlı bir ilişki tespit edilmiştir. Aynı çalışmada Barron and Kenny (1986) tarafından önerilen yöntem dâhilinde astların algılanan örgütsel vatandaşlık davranışları arasında liderin duygusal zekasının aracılık rolü incelenmiş olup anlamlı bir etkiye rastlanılmamıştır.

Yine Çarıkçı, Kanten ve Kanten (2010) tarafından üniverisite akademik personelinin kişilik özellikleri, duygusal zeka ve ÖVD arasındaki ilişkiyi tespit etmek amacıyla yürüttükleri çalışmalarında duygusal zeka ile ÖVD arasında pozitif yönlü anlamlı bir ilişki belirlemişlerdir.

Benzer bir bulgu Tokmak, Yıldız ve Turgut (2013) tarafindan duygusal zekanın, ÖVD üzerine etkisi ve bu etkide iş tatmininin aracılık rolünün bulunup bulunmadığını belirlemek amacıyla çeşitli sektörlere mensup 243 işgörenin katılımı ile gerçekleştirdikleri araştırma sonucunda elde edilmiştir. Buna göre duygusal zekanın ÖVD ve iş tatmini üzerinde pozitif bir etkiye sahip olduğu ancak bu etkide iş tatmininin aracılık rolünün bulunmadığı tespit edilmiştir.

Bu bulguların aksine Gürbüz ve Yüksel (2008) tarafından duygusal zeka ile performans, iş doyumu, ÖVD ve çeşitli demografik özellikler arasındaki ilişkilerin incelenmesi amacıyla bankacılık, hazır giyim, turizm, medikal malzeme ticareti, tekstil üretimi ve perakende satış sektörlerinde çalışan işgörenler üzerinde yapılan araştırmada duygusal zeka ile ÖVD arasında herhangi bir anlamlı ilişkiye rastlanılmamıştır.

Konuyla ilgili yabancı yazında gerçekleştirilen araştırmalarda da benzer sonuçlara ulaşıldığı görülmektedir. örneğin Antony (2013) tarafından duygusal zeka ile örgütsel vatandaşlık davranışları arasındaki ilişkiyi incelemek amacıyla özel bir şirketin 115 yöneticisi üzerinde yürütülen çalışmada yöneticilerin duygusal zekaları ile çalışanların örgütsel vatandaşlık davranışları arasında pozitif yönlü anlamlı bir ilişkinin varlığı belirlenmiştir.

Yine Carmali ve Josman (2006) çeşitli alanlarda faaliyet gösteren 215 çalışandan oluşan örneklem üzerinde duygusal zeka, görev performansı ve 
örgütsel vatandaşlık davranışları arasında ilişkiyi inceledikleri çalışmalarında pozitif yönlü anlamlı bir ilişkinin bulunduğu sonucuna varmışlardır.

Son olarak Maini, Singh ve Kaur (2012) tarafından enerji santrallerinde çalışan teknik ve teknik olmayan 250 işgören üzerinde gerçekleştirilen araştırmada da duygusal zekanın alt boyutları (duyguları algılama, kendi duygularını düzenleme, başkalarının duygularını anlama ve duyguları kullanma) ile ÖVD alt boyutları (özgecilik, sportmenlik, vicdanlılık, nezaket ve sivil erdem) arasında pozitif yönlü anlamlı ilişkiler tespit edilmiştir.

\section{YÖNTEM}

\section{A. Araştırma Deseni}

Çalışanların duygusal zekaları ile örgütsel vatandaşlık davranışları arasındaki ilişkiyi inceleyen bu çalışmada amaca uygun olarak ilişkisel tarama modeli benimsenmiştir. İlişkisel tarama modelleri, esas itibariyle iki veya daha fazla sayıda değişken arasında ilişki olup olmadığını varsa bu ilişkinin derecesini belirlemeyi amaçlayan araştırma modelleridir (İlhan vd., 2013:126).

\section{B. Örneklem}

Çalışma kolayda örnekleme yöntemi kullanılarak tamamen gönüllülük esasına göre katılmayı kabul eden Denizli ili merkez ilçe şubelerinde görev yapan 210 özel banka çalışanı üzerinde yürütülmüştür. Araştırmaya katılan çalışanların \% 39'u kadın, \%61'i ise erkektir. Çalışma grubunun yaş dağılımına bakıldığında, katılımcıların \%47,5’i 20-29 yaş, \%36,5’i 30-39 yaş, \%11’i 40-49 yaş ve \%5’i 50 yaşın üzerindedir. Medeni durumları itibariyle katılımcıların \%60'ı evli, \%40’1 bekârdır. Eğitim düzeyleri itibariyle katılımcıların \%83,5’i lisans, \%14,5’i yüksek lisans ve \%2'si doktora mezunudur. Hizmet süreleri dikkate alındığında \% 54,5’i 1-5 yıl, \% 20,5’i 6-10 yıl, \% 13,5’i 11-15 y1l, \% 6,5’i 16-20 yıl ve \% 5’i 21 yıl ve üstü çalışma süresine sahiptir.

Araştırma kapsamında analiz edilecek veriler anket tekniği kullanılarak toplanmıştır. Verilerin toplanması bir aylık bir süre zarfında gerçekleşmiştir. Katılımcıların bazılarına (kent merkezine yakın şubelerde çalışanlar) anketler doğrudan elden dağıtılırken bazılarına (kent merkezine uzak şubelerde çalışanlar) posta yardımıyla ulaştırılmıştır. Toplamda 250 adet anket dağıtılmış olup 215 tanesi geri dönmüştür. Geri dönen anketlerin kayıp veri ve uç değerler açısından incelenmeleri sonucunda 5 tanesinin analiz için uygun olmadığ1 belirlenmiş ve 210 tanesi üzerinde analizler gerçekleştirilmiştir. 


\section{Veri Toplama Araçları}

Hazırlanan anket üç bölümden oluşmaktadır. Birinci bölümde katılımcıların demografik özellikleri, ikinci bölümde duygusal zeka, üçüncü bölümde örgütsel vatandaşlık davranışı ile ilgili sorular yer almaktadır. Veri toplamak için kullanılan ölçeklerle ilgili bilgiler aşağıda verilmektedir.

Duygusal Zeka Ölçeği: Wong ve Law (2002) tarafından geliştirilen ölçek her biri dörder maddeden oluşan dört boyutlu bir yapıya sahiptir. Her bir madde 5’li likert ölçeği (1, "Hiç katılmıyorum"dan 5, "Kesinlikle katılıyorum"a doğru) ile değerlendirilmiş olup ölçeğin alt boyutlarına ilişkin iç tutarlılık katsayıları (Cronbach's alpha) sırasıyla Duyguları Algılama için a=0.836; Başkalarının Duygularını Anlama için $\mathrm{a}=0.721$; Duyguları Kullanma için $\mathrm{a}=0.720$ ve duyguları düzenleme için a=0.812 olarak hesaplanmıştır.

Örgütsel Vatandaşlık Davranışı Ölçeği: Basım ve Şeşen (2006) tarafından Campbell (2004) ve Williams ve Shiaw (1999)'ın çalışmalarında kullandıkları iki farklı ölçeğin birleştirilmesi suretiyle geliştirilmiş bir ölçek olup Organ (1988) tarafından ortaya konan ÖVD boyutları ile uyumludur. Ölçek maddelerine verilen cevaplar 5'li Likert derecelendirmesine göre tasarlanmıştır. "Diğerkâmlık"(5 madde), "Vicdanlılık" (3 madde), "Nezaket" (3 madde), "Centilmenlik" (4 madde) ve "Sivil Erdem" (4 madde) olmak üzere toplam beş alt boyuttan oluşan ölçeğin iç tutarlılık katsayıları sırasıyla a=0.924, 0.836, $0.873,0.786$ ve 0.772 olarak hesaplanmıştır.

\section{Verilerin Analizi}

Çalışanların duygusal zekaları ile örgütsel vatandaşlık davranışları asındaki ilişkinin belirlenmesi amacıyla kanonik korelasyon analizinden yararlanılmıştır. Kanonik korelasyon analizi, aynen faktör analizinde olduğu gibi en karmaşık işlem aşamalarını gerekli kılan çok değişkenli analiz teknikleri arasında yer almaktadır (Keskin ve Özsoy, 2004:67). Bu analiz, " $n$ " tane gözlemin oluşturduğu " $q$ " tane bağımsız değişken (X) ile "p" tane bağımlı değişkenin (Y) doğrusal bileşenlerinden türetilmiş kanonik değişken çiftleri arasındaki maksimum korelasyonu veren doğrusal bileşen çiftlerinin araştırılması esasına dayanır (Sayın, Koğar ve Çakan, 2012:211). Bir başka ifade ile çok değişkenli bir anakütleden çekilmiş iki farklı değişken seti arasındaki ilişkiyi incelemektedir. Genel olarak şu şekilde ifade edilmektedir:

$$
\mathrm{X}_{1}+\mathrm{X}_{2}+\mathrm{X}_{3}+\mathrm{X}_{4}+\mathrm{X}_{5} \ldots \ldots \mathrm{X}_{\mathrm{q}}=\mathrm{Y}_{1}+\mathrm{Y}_{2}+\mathrm{Y}_{3}+\mathrm{Y}_{4}+\mathrm{Y}_{5} \ldots \ldots \ldots \mathrm{Y}_{\mathrm{p}}
$$

(Metrik veya metrik olmayan) (Metrik veya metrik olmayan) 
Kanonik korelasyon analizinde temel olarak, $\mathrm{X}$ ve $\mathrm{Y}$ değişken kümelerinin her biri için, maksimum korelasyonlu ve birim varyanslı birbirinden bağımsız doğrusal bileşenler elde edilmektedir. Elde edilecek olan maksimum doğrusal bileşen sayısı, araştırmaya konu olan değişken kümelerinden küçük olanın, değişken sayısı ile sınırlıdır (Çankaya, 2005:4). Kanonik değişken olarak ifade edilen değişkenlerin doğrusal kombinasyonları şu şekildedir:

$$
\begin{gathered}
\mathrm{V}_{1}=\mathrm{a}_{1} \mathrm{X}_{1}+\mathrm{a}_{2} \mathrm{X}_{2}+\mathrm{a}_{3} \mathrm{X}_{3} \ldots \mathrm{a}_{\mathrm{q}} \mathrm{X}_{\mathrm{q}} \\
\mathrm{W}_{1}=\mathrm{b}_{1} \mathrm{Y}_{1}+\mathrm{b}_{2} \mathrm{Y}_{2}+\mathrm{b}_{3} \mathrm{Y}_{3}+\ldots . \mathrm{b}_{\mathrm{p}} \mathrm{Y}_{\mathrm{p}}
\end{gathered}
$$

$\mathrm{V}_{1}$ ve $\mathrm{W}_{1}$ kanonik değişken çiftleri arasındaki korelâsyon $\mathrm{C}_{1}$ olarak kabul edilirse kanonik korelâsyon analizinin amac1 $a_{1}, a_{2} \ldots . a_{q}$ ve $b_{1}, b_{2} \ldots . . b_{p}$ gibi kısmi kanonik korelasyon katsayılarını $\mathrm{C}_{1}$ değerini maksimum kılacak şekilde tahmin etmektir (Yıldırım, Albayrak, Gümüş ve Akalın, 2011:171).

$\mathrm{Bu}$ doğrultuda mevcut araştırma kapsamında aşağıdaki sorulara yanıt aranacaktır;

1. Çalışanların duygusal zekaları sergiledikleri örgütsel vatandaşlık davranışlarının ne kadarını yordamaktadır?

2. Çalışanların duygusal zekaları ile örgütsel vatandaşlık davranışları arasında ne düzeyde bir ilişki vardır?

\section{BULGULAR}

K.K.A ile biri " $q$ " tane değişkenden, diğeri ise "p" tane değişkenden oluşan iki değişken seti elde edilmiştir. Bunlardan set 1 (Duygusal Zeka) "q" tane bağımsız değişkenden oluşmaktadır ve bu çalışmada sırasıyla $\mathrm{X}_{1}$ : Duyguları Algılama, $\mathrm{X}_{2}$ : Başkalarının Duygularını Anlama, $\mathrm{X}_{3}$ : Duyguları Kullanma, $\mathrm{X}_{4}$ : Duyguları (Kontrol Etme) Düzenleme değişkenlerini içerir. Set 2 (ÖVD) ise "p" tane bağımlı değişkeni ifade eder ki $\mathrm{Y}_{1}$ : Diğergamlık, $\mathrm{Y}_{2}$ : Sivil Erdem, $\mathrm{Y}_{3}$ : Vicdanlılık, $\mathrm{Y}_{4}$ : Nezaket ve $\mathrm{Y}_{5}$ : Centilmenlik değişkenlerinden oluşmaktadır. $\mathrm{Bu}$ değişkenlere ilişkin tanımlayıcı istatistikler tablo 1'de verilmiştir. 
Tablo 1: Çalışmada Ele Alınan Bağımlı ve Bağımsız Değişkenlere Ait Tanımlayıcı İstatistikler.

\begin{tabular}{lccc}
\hline Set -1: Duygusal Zeka & Ort.(x) & SS & N \\
\hline $\mathrm{X}_{1}:$ Duyguları Algılama & 2,6508 & 0,77414 & 210 \\
$\mathrm{X}_{2}$ : Başkalarının Duygularını Anlama & 3,6050 & 0,77123 & 210 \\
$\mathrm{X}_{3}$ : Duyguları Kullanma & 2,6500 & 0,75869 & 210 \\
$\mathrm{X}_{4}$ : Duyguları (Kontrol Etme) & 2,1659 & 0,57284 & 210 \\
Düzenleme & Ort.(x) & $\mathbf{S S}$ & $\mathbf{N}$ \\
\hline Set -2: ÖVD & 3,0752 & 0,71737 & 210 \\
\hline $\mathrm{Y}_{1}:$ Diğergamlik & 2,5705 & 0,77208 & 210 \\
$\mathrm{Y}_{2}:$ Sivil Erdem & 2,8163 & 0,49466 & 210 \\
$\mathrm{Y}_{3}:$ Vicdanlılık & 2,9500 & 1,03463 & 210 \\
$\mathrm{Y}_{4}:$ Nezaket & 3,0501 & 0,79779 & 210 \\
$\mathrm{Y}_{5}:$ Centilmenlik & &
\end{tabular}

Tablo 1 incelendiğinde bağımsız değişkenlere ilişkin puan ortalamalarının sirasıyla $X_{2}(=3,6050), X_{1}(=2,6508), X_{3}(=2,6500)$ ve $X_{4}(=2,1659)$; bağımlı değişkenlere ilişkin puan ortalamalarının ise sırasıyla $Y_{1}(=3,0752), Y_{5}$ $(=3,0501), Y_{4}(=2,9500), Y_{3}(=2,8163)$ ve $Y_{2}(=2,5705)$ biçiminde gerçekleştiği görülmektedir. $\mathrm{Bu}$ durumda katılımcıların çevrelerindeki insanların duygularını algılamaları ve anlamalarıyla ilgili yeteneklerinin $\left(\mathrm{X}_{2}\right)$ ve kendileri dışında diğer çalışanlara işleriyle ilgili konularda ihtiyaç duydukları zamanda tamamen gönüllü olarak ve her hangi bir karşılık beklemeksizin isteğe bağlı ortaya koydukları fayda sağlayıcı davranışları $\left(\mathrm{Y}_{1}\right)$ gösterme eğilimlerinin yüksek olduğu söylenebilir.

KKA, bağımsız ve bağımlı değişkenler arasındaki korelasyonu araştırmayı ve bunu en fazla etkileyen kanonik değişkeni belirlemeyi amaçlamaktadır (Çemrek, 2012:206). Kononik değişken sayısı bağımsız ve bağımlı değişken setlerinden hangisi daha az sayıda ise ona eşittir. Bu çalışmada dört değişken ile bağımsız değişken seti daha az sayıya sahip olduğu için dört kanonik değişken hesaplanmıştır. Hesaplanan kanonik korelasyon değerleri ile Wilk's lamda anlamlılık testine ilişkin sonuçlar tablo 2'de yer almaktadır. 
Tablo 2: Kanonik Değişkenlere Ait Korelasyon Katsayıları, Wilks' Lambda ve Anlamlilik Testleri

\begin{tabular}{cccccc}
\hline $\begin{array}{c}\text { Kanonik } \\
\text { Değişken } \\
\text { Çifti }\end{array}$ & $\begin{array}{c}\text { Kanonik } \\
\text { Korelasyon }\end{array}$ & Wilk's & Chi-sQ & DF & Sig \\
\hline 1 & 0,723 & 0,370 & 203,002 & 20,000 & 0,000 \\
2 & 0,148 & 0,973 & 4,406 & 4,000 & 0,441 \\
3 & 0,163 & 0,968 & 6,680 & 6,000 & 0,351 \\
4 & 0,075 & 0,994 & 1,161 & 2,000 & 0,559 \\
\hline
\end{tabular}

Tablo 2 incelendiğinde birinci kanonik değişken kümesi hariç diğerlerinin anlamlı olmadığı görülmektedir $(p>0,05)$. Kanonik değişkenlerden sadece anlamlı olanların yorumlanması yeterlidir. Dolayısıyla bundan sonraki aşamalarda yapılan yorumlar birinci kanonik değişken kümesine yönelik olacaktır.

Kanonik korelasyon analizinde bağımlı ve bağımsız değişkenler arasında açıklanan ortak varyans hesaplanan kanonik korelasyon katsayılarının karelerine eşittir. Bu çalışmayla ilgili olarak dört farklı kanonik korelasyon kümesi için hesaplanan korelasyon katsayıları (C) ve ortak varyansların ( ${ }^{2}$ ) sirasiyla, $\mathrm{C}_{1}=0,723$ (ortak varyans $\% 52,27$ ); $\mathrm{C}_{2}=0,148$ (ortak varyans \%2,19); $\mathrm{C}_{3}=0,163$ (ortak varyans \%2,65), $\mathrm{C}_{4}=0,075$ (ortak varyans $\% 0,5$ ) biçiminde olduğu görülmektedir.

Kanonik korelasyon katsayıları değişken setlerinin birbirini açıkladığı varyansı değil de $\mathrm{X}$ ve $\mathrm{Y}$ değişkenlerinin doğrusal bileşimleri arasındaki korelasyonları maksimize ettiği için elde edilen yüksek kanonik korelasyon katsayıları her zaman için $\mathrm{X}$ ve $\mathrm{Y}$ değişken setleri arasında güçlü bir korelasyonun olduğu anlamina gelmez. Bu nedenle değişken setlerinden herhangi birinin diğerinin varyansını hangi düzeyde açıkladığını belirleyebilmek için Stewart ve Love (1968) tarafından önerilen gereksizlik ölçülerinin kullanılması gerekmektedir (Albayrak, 2010:252). Gereksizlik Analizi ile ilgili bulgular Tablo 3'te verilmiştir. 
Tablo 3: Gereksizlik Analizi (Redundancy Analysis)

\begin{tabular}{cccccccc|}
\hline \multicolumn{2}{c}{$\begin{array}{c}\text { Duygusal Zeka Değişkenlerinin } \\
\text { Aç1klanan Varyansı } \\
\text { (Set-1) }\end{array}$} & \multicolumn{3}{c|}{$\begin{array}{c}\text { Örgütsel Vatandaşlık Davranışı } \\
\text { Değişkenlerinin Aç1klanan Varyans1 } \\
\text { (Set-2) }\end{array}$} \\
\hline $\begin{array}{c}\text { Kendi Kanonik } \\
\text { Değişkeni } \\
\text { Tarafindan }\end{array}$ & \multicolumn{2}{c}{$\begin{array}{c}\text { Karşıt Kanonik } \\
\text { Değişkeni } \\
\text { Tarafından }\end{array}$} & $\begin{array}{c}\text { Kendi Kanonik } \\
\text { Değişkeni } \\
\text { Tarafından }\end{array}$ & $\begin{array}{c}\text { Karşıt Kanonik } \\
\text { Değişkeni } \\
\text { Tarafindan }\end{array}$ \\
\hline CV1-1 & $\underline{\mathbf{0 , 2 4 8}}$ & CV2-1 & 0,129 & CV2-1 & $\underline{\mathbf{0 , 2 6 5}}$ & CV1-1 & 0,138 \\
CV1-2 & 0,191 & CV2-2 & 0,084 & CV2-2 & 0,185 & CV1-2 & 0,057 \\
CV1-3 & 0,173 & CV2-3 & 0,005 & CV2-3 & 0,148 & CV1-3 & 0,004 \\
CV1-4 & 0,160 & CV2-4 & 0,001 & CV2-4 & 0,191 & CV1-4 & 0,001 \\
\hline
\end{tabular}

Tablo 3'e göre anlamlı olan birinci kanonik değişken kümesi duygusal zeka setindeki değişkenliğin \%25’ini, örgütsel vatandaşl1k setindeki değişkenliğin \% 27'sini açıklamaktadır. Bununla birlikte ÖVD kanonik değişkeninin (CV2.1) DZ değişkenlerinin toplam varyansının \%13'lük $\left(0.248 \times 0.723^{2}\right)$ bir kısmını açıklamasına karşın, DZ kanonik değişkeninin (CV1.1) ÖVD değişkenlerinin toplam varyansının \% 14 'lük $\left(0.265 \times 0.723^{2}\right)$ bir kısmını açıkladığı belirlenmiştir. Bu sonuçlara göre birinci kanonik korelasyon değerinin düşük düzeyde pratik anlamlılı̆ga sahip olduğu söylenebilir.

Birinci kanonik değişken kümesine ait standardize edilmiş kanonik katsayılar, kanonik yükler ve kanonik çapraz yükler Tablo 4'te yer almaktadır.

Tablo 4: Değişkenlerin Standartlaştırılmış Korelasyon Katsayıları, Kanonik Yükleri Ve Kanonik Çapraz Yükleri

\begin{tabular}{lccc}
\hline Set 1: Duygusal Zeka & $\begin{array}{c}\text { Std. Kan. } \\
\text { Kat. }\end{array}$ & $\begin{array}{c}\text { Kanonik } \\
\text { Yükler }\end{array}$ & $\begin{array}{c}\text { Kanonik } \\
\text { Capraz } \\
\text { Yükler }\end{array}$ \\
\hline $\mathrm{X}_{1}$ : Duyguları Algılama & $-0,966$ & $-0,829$ & $-0,599$ \\
$\mathrm{X}_{2}$ : Başkalarının Duygularını Anlama & $-0,146$ & $-0,487$ & $-0,352$ \\
$\mathrm{X}_{3}$ : Duyguları Kullanma & $-0,567$ & $-0,207$ & $-0,149$ \\
$\mathrm{X}_{4}$ : Duygular1 (Kontrol Etme) Düzenleme & $-0,071$ & $-0,156$ & $-0,113$ \\
\hline Set 2: ÖVD & Std. Kan. & Kanonik & Kanonik \\
& Kat. & Yükler & Capraz \\
& & & Yükler \\
\hline $\mathrm{Y}_{1}$ : Diğergamlık & 0,105 & $-0,401$ & $-0,218$ \\
$\mathrm{Y}_{2}$ : Sivil Erdem & $-0,602$ & $-0,535$ & $-0,387$ \\
$\mathrm{Y}_{3}$ : Vicdanlılık & $-1,717$ & $-0,907$ & $-0,655$ \\
$\mathrm{Y}_{4}$ : Nezaket & 0,000 & $-0,196$ & $-0,141$ \\
$\mathrm{Y}_{5}$ : Centilmenlik & $-0,054$ & $-0,297$ & $-0,215$ \\
\hline
\end{tabular}


Standartlaştırılmış kanonik katsayılar ilgili değişkenin kanonik değişkenlerin tanımlanmasındaki standart ağırlıklarını göstermektedir (Albayrak, 2010:251). Set 1'de yer alan değişkenlerin birinci kanonik değişkenle olan ilişkilerini dikkate alarak oluşturulan denklem şu şekildedir:

$$
\mathrm{V}_{1}=\mathrm{a}_{1} \mathrm{X}_{1}+\mathrm{a}_{2} \mathrm{X}_{2}+\mathrm{a}_{3} \mathrm{X}_{3} \ldots \mathrm{a}_{\mathrm{q}} \mathrm{X}_{\mathrm{q}}=-0,96 \mathrm{X}_{1}-0,14 \mathrm{X}_{2}-0,56 \mathrm{X}_{3}-0,07 \mathrm{X}_{4}
$$

Set 1 (DZ) içindeki değişkenlerden birinci kanonik değişkene en fazla katkıyı $\mathrm{X}_{1}$ (Duyguları algılama) yapmıştır.

Set 2'de yer alan değişkenlerin birinci kanonik değişkenle olan ilişkilerini dikkate alarak oluşturulan denklem ise şu şekildedir:

$$
\mathrm{W}_{1}=\mathrm{b}_{1} \mathrm{Y}_{1}+\mathrm{b}_{2} \mathrm{Y}_{2}+\mathrm{b}_{3} \mathrm{Y}_{3}+\ldots \mathrm{b}_{\mathrm{p}} \mathrm{Y}_{\mathrm{p}}=0,10 \mathrm{Y}_{1}-0,60 \mathrm{Y}_{2}-1,71 \mathrm{Y}_{3}-0,05 \mathrm{Y}_{5}
$$

Set 2 (ÖVD) içindeki değişkenlerden birinci kanonik değişkene en fazla katkıyı $\mathrm{Y}_{3}$ (Vicdanlılık) yapmıştır.

Her bir değişkenin içerisinde yer aldığı kanonik değişken kümesinin bir üyesi olabilmesi için kanonik değişkenle arasındaki korelasyonun \%30'dan büyük olması gerekir (Sayın, Koğar ve Çakan, 2012:216). Bu koşulu sağlamayan değişkenler o kümeye dâhil edilmemelidir. Tablo 4'te görüldüğü üzere DZ kanonik değişken kümesi içinde yer alan değişkenlerden sadece $\mathrm{X}_{1}$ : Duyguları Algılama $(\% 82,9)$ ve $\mathrm{X}_{2}$ : Başkalarının Duygularını Anlama $(\% 48,7)$ değişkenleri bu koşulu sağlamaktadır. Diğer taraftan ÖVD kanonik değişken kümesi içinde yer alan değişkenlerden de sadece $\mathrm{Y}_{1}$ :Diğergamlık $(\% 40,1), \mathrm{Y}_{2}$ :Sivil Erdem $(\% 53,5)$ ve $\mathrm{Y}_{3}$ :Vicdanlılık $(\% 90,7)$ değişkenleri bu koşulu sağlamaktadırlar. Bu sonuçlara göre $\mathrm{V}_{1}$ (DZ) ve $\mathrm{W}_{1}$ (ÖVD) kanonik değişkenlerinin tanımlanmasında en önemli değişkenlerin sirasıyla $X_{1}(\% 82,9), X_{2}(\% 48,7), Y_{3}(\% 90,7), Y_{2}(\% 53,5)$ ve $\mathrm{Y}_{1}(\% 40,1)$ değişkenleri olduğu söylenebilir.

\section{SONUÇ}

$\mathrm{Bu}$ çalışma ile üzerinde çok az sayıda araştırma yapılmış olan duygusal zeka ile örgütsel vatandaşlık davranışı arasındaki ilişki incelenmeye çalışılmıştır. Çalışanların duygusal zekaları bağımsız değişken (set 1), örgütsel vatandaşlık davranışları ise bağımlı değişken (set 2) olarak tanımlanmış ve kanonik korelasyon analizi uygulanmıştır.

KKA sonucunda ilgili değişken setlerine ilişkin elde edilen dört kanonik fonksiyondan yalnızca birinci kononik fonksiyonun \%5 anlamlılık düzeyinde istatistik açıdan anlamlı olduğu belirlenmiş ve yorumlar birinci kanonik fonksiyon dikkate alınarak yapılmıştır. Buna göre DZ ve ÖVD değişken setleri arasında \%72,3 düzeyinde bir korelasyon katsayısı tespit edilmiş olup 
aralarında paylaştıkları ortak varyans miktarı \%52,27 olarak belirlenmiştir. Ancak kanonik korelasyon katsayıları değişken setlerinin birbirini açıkladığı varyansı değil de set 1 ve set 2 değişkenlerinin doğrusal bileşimleri arasındaki korelasyonları maksimize ettiği için elde edilen yüksek kanonik korelasyon katsayılarına aldanmamak gerekir. Bu yüzden kanonik korelasyon katsayısı yerine gereksizlik ölçülerinin kullanılması önerilmiştir. Buna göre ÖVD değişkenlerine ilişkin varyansın yaklaşık \%27'si kendi kanonik değişkeni tarafından açıklanırken yaklaşık \%14'ü $\left(0.265 \times 0.723^{2}\right)$ karşıt kanonik değişken olan DZ tarafından açıklanabilmiştir. Dolayısıyla DZ'nın ÖVD'nı yordama gücünün zayıf olduğu söylenebilir. Benzer sonuç Dirican (2013) tarafından yürütülen çalışmada elde edilmiştir. Buna göre çalışanların örgütsel vatandaşlık davranışlarındaki değişimin sadece \%21'inin duygusal zekanın dört boyutu tarafından açıklandığı belirlenmiştir. Aynı şekilde Maini, Singh ve Kaur (2012) tarafından yapılan çalışmada da DZ değişkenlerinin ÖVD değişkenlerine ait varyansın \%9'unu açıkladığı sonucuna varılmıştır. $\mathrm{Bu}$ durum literatürdeki çelişkili DZ ve ÖVD ilişkisi ile uyuşmaktadır. Bazı çalışmalar (Antony, 2013; Tokmak, Yıldız ve Turgut, 2013; Çarıkçı, Kanten ve Kanten, 2010; Carmali ve Josman 2006) bu iki değişken arasında önemli bir ilişki olduğu yönünde bulgulara ulaşırken bazıları (Gürbüz ve Yüksel, 2008; Shaffer ve Shaffer, 2005) aralarında anlamlı bir ilişkinin olmadığı yönünde sonuçlara ulaşmışlardır.

KKA'nde değişken kümesi içerisinde yer alacak değişkenlerin belirlenmesinde kanonik değişkenle aralarındaki korelasyon düzeyi (en az \%30) belirleyici olmaktadır. DZ kanonik değişken kümesi içinde yer alan değişkenlerden sadece Duyguları Algılama $(\% 82,9)$ ve Başkalarının Duygularını Anlama $(\% 48,7)$ değişkenlerinin bu koşulu sağladığı belirlenmiştir. Diğer taraftan ÖVD kanonik değişken kümesi içinde yer alan değişkenlerden de sadece Diğergamlık $(\% 40,1)$, Sivil Erdem $(\% 53,5)$ ve Vicdanlılık $(\% 90,7)$ değişkenleri bu koşulu sağlamaktadırlar. Ayrıca söz konusu değişkenlerin tamamının aynı işarete sahip olması aralarında aynı yönde bir ilişkinin varlığını göstermektedir. Bunun anlamı DZ değişkenlerinden Duyguları Algılama ve Başkalarının Duygularını Anlama değişkenleri ile ÖVD değişkenlerden Diğergamlık, Sivil Erdem ve Vicdanlılık değişkenleri arasında pozitif bir ilişki vardır. Dolayısıyla sahip olduğu duygularını, yaşadığı ruh halini ve içinde bulunduğu durum ve şartların sebeplerini anlayabilen bir çalışanın çevresinde yer alan kişi veya kişilerin davranışlarından ne hissettiklerini anlayabileceğini ve örgütün menfaatlerini ön planda tutarak diğer çalışanlara işleriyle ilgili konularda ihtiyaç duydukları zamanda kendi işini aksatmadan tamamen gönüllü olarak 
ve her hangi bir karş11ı beklemeksizin fayda sağlayıcı davranışlar ortaya koyabileceğini söylemek mümkündür. Bu bulgular konuyla ilgili benzer çalışma bulgularıyla paralellik göstermektedir (Dirican, 2013; Maini, Singh ve Kaur, 2012).

Sonuç olarak denilebilir ki literatürde her ne kadar DZ ile ÖVD arasındaki ilişki net bir biçimde ortaya konulamamış olsa da bu ve benzeri çalışmalarda elde edilen bulgular asgari düzeyde de olsa bir ilişkinin var olduğunu kanıtlamaktadır. Bu çalışmada ele alınmamış olmakla birlikte iş tatmini, iş performansı ve örgütsel bağlılık gibi örgütsel değişkenlerle olan ilişkisini ortaya koyan çok sayıdaki araştırma bulgularına da dayanarak DZ'nın örgütler açısından ne kadar önemli olduğu anlaşılmaktadır. Yüksek duygusal zekaya sahip çalışanların örgütlerinin yararına olabilecek tutum ve davranışları gösterme eğilimlerinin de artacağı dikkate alındığında personel seçimi ve işe yerleştirilmesi sürecinde adayların bu açıdan da değerlendirilmesinin yararlı olacağ1 düşünülmektedir.

\section{KAYNAKÇA}

ACAR, Füsun, (2002), "Duygusal Zeka ve Liderlik", EÜ, Sosyal Bilimler Enstitüsü Dergisi, S.12, (ss.53-68).

AHMAD, Summiya, BANGASH, Hayat and KHAN, Sheraz Ahmad, (2009), "Emotional Intelligence And Gender Differences", Sarhad J. Agric. Vol.25, No.1, (pp.127-130).

ALBAYRAK, Ali Sait (2005). "Kanonik Korelâsyon Analizi”, SPSS Uygulamalı Çok Değişkenli İstatistik Teknikleri, (ed. Şeref Kalayc1), Asil Yayın Dağıtım, Ankara, (ss.237-257).

ANTONY, Janis Maria, (2013), "The Influence Of Emotional Intelligence on Organizational Commitment And Organizational Citizenship Behavior", International Journal of Social Science \& Interdisciplinary Research IJSSIR, Vol. 2, No. 3, (pp.110-115).

ATALAY, Ceren, (2009). Personel Güçlendirmeye Dayalı İnsan Kaynakları Yönetimi İşlevlerinin Örgütsel Vatandaşlık Davranışına Etkisi Ve Eczacıbaşı Topluluğu'nda Bir Araştırma, Dumlupınar Üniversitesi Sosyal Bilimler Enstitüsü Yayınlanmamış Doktora Tezi, Kütahya.

BASIM, H.Nejat ve ŞEŞEN, Harun, (2006), "Örgütsel Vatandaşlık Davranış1 Ölçeği Uyarlıma ve Karşılaştırma Çalışması”, Ankara Üniversitesi SBF Dergisi, C.61, No.4, (ss.83-101). 
BERBEROĞLU, N. (2013). Psikolojik Sermayenin Örgütsel Vatandaşlik Davranış1 Üzerine Etkisi: Bir Alan Araştırmas1, Gazi Üniversitesi Sosyal Bilimler Enstitüsü Yayınlanmamış Yüksek Lisans Tezi, Ankara.

CARMALİ, Abraham and JOSMAN, Zvi E. (2006), "The Relationship Among Emotional Intelligence, Task Performance, and Organizational Citizenship Behaviors", Human Performance, Vol.19, No.4, (pp.403-419).

CHAHAL, Hardeep and MEHTA, Shivani, (2011), "Antecedents And Consequences Of Organisational Citizenship Behaviour (Ocb): A Conceptual Framework in Reference To Health Care Sector", Journal of Services Research, Vol. 10, No. 2, (pp.25-45).

CINGISİZ, Neşe ve MURAT, Mehmet, (2010). "Evlenmek için birbirlerini tercih eden çiftlerin duygusal zeka düzeylerinin bazı değişkenler açısından incelenmesi”, Gaziantep Sosyal Bilimler Dergisi, Cilt.9 , S.1, (ss.99-114). COBB, Casey D. and MAYER, John.D. (2000), "Emotional Intelligence", Educational Leadership, Vol.58, No.3, (pp.14-19).

ÇAKAR, Ulaş ve Arbak Yasemin, (2004), "Modern Yaklaşımlar Işı̆̆ında Değişen Duygu Zeka İlişkisi ve Duygusal Zeka”, D.E.Ü. Sosyal Bilimler Enstitüsü Dergisi, Cilt.6, S.3, (ss.23-48).

ÇANKAYA, Soner, (2005), Kanonik Korelasyon Analizi Ve Hayvanc1likta Kullanımı, Çukurova Üniversitesi Fen Bilimleri Enstitüsü Yayınlanmamış Doktora Tezi, Adana.

ÇAPRAZ, Burak, KESKEN, Jülide, AYYILDIZ, N.Ayşe ve İLİC, Derya, (2009), "Yönetsel Zeka'ya Doğru: Yönetsel Zeka ve Bleşenlerini Tanımlamaya Yönelik Kavramsal Bir Çalışma”, Ege Akademik Bakış, Cilt.9, S. 1, (ss. 187-211).

ÇARIKÇI, İlker, KANTEN, Selahattin ve KANTEN, Pelin, (2010), "Kişilik, Duygusal Zeka Ve Örgütsel Vatandaşlık Davranışları Arasındaki İlişkileri Belirlemeye Yönelik Bir Araştırma”, Süleyman Demirel Üniversitesi Sosyal Bilimler Enstitüsü Dergisi, Y11.2010/1, S.11,(ss.41-65).

ÇEMREK, Fatih, (2012), "Türkiye'deki İllerin Gelir ve Refah Düzeyi Değişkenleri Arasındaki İlişkinin Kanonik Korelasyon Analizi ile İncelenmesi”, Eskişehir Osmangazi Üniversitesi İIBF Dergisi, Cilt. 7, S.2,(ss.197-215). DİRİCAN, Ayşe Hatun, (2013), Duygusal Zekanın Örgütsel Vatandaşlık Davranışı Ve Üretkenlik Karşıtı Davranışlar Üzerine Etkisi, Gebze Yüksek Teknoloji Enstitüsü Sosyal Bilimler Enstitüsü Yayımlanmamış Yüksek Lisans Tezi, GEBZE.

FERNANDEZ-BERROCAL, Pablo, ALCAIDE, Rocio, EXTREMERA, Natalio and PIZARRO, David, (2006), "The Role of Emotional Intelligence in Anxiety and Depression among Adolescents”, Individual Differences Research, 
Vol.4, No.1, (pp.16-27).

FİORI, Marina and ANTONAKIS, John, (2011), "The ability model of emotional intelligence: Searching for valid Measures", Personality and Individual Differences, Vol.50, No.3, (pp.329-334).

GİRGIN, Günseli, (2009), "Üniversite Öğrencilerinde Duygusal Zekanın Bazı Değişkenler Açısından İncelenmesi”, KKTC-Milli Eğitim Dergisi, Cilt.3, (ss.1-12).

GRAHAM, Jill W. and VAN DYNE,Linn, (2006), "Gathering Information and Exercising Influence: Two Forms of Civic Virtue Organizational Citizenship Behavior", Employ Respons Rights , No.18, (pp.89-109).

GÜRBÜZ, Sait ve YÜKSEL, Murad, (2008), "Çalışma Ortamında Duygusal Zeka: İş Performansı, İş Tatmini, Örgütsel Vatandaşlık Davranışı Ve Bazı Demografik Özelliklerle İlişkisi”, Doğuş Üniversitesi Dergisi, Cilt.9, S. 2, (ss.174-190).

HANS, Arvind, MUBEEN, Soofi Asra and SAİD AL RABANİ, Ruwaiya Salim, (2013), “A Study On Emotional Intelligence Among Teachers: A Case Study of Private Educational Institutions in Muscat", International Journal of Application or Innovation in Engineering \& Management, Vol. 2, No. 7, (pp.359-366).

İLHAN, Mustafa, ÇETIN, Bayram, ÖNER-SÜNKÜR, Meral ve YILMAZ, Ferat, (2013), "Ders Çalışma Becerileri ile Akademik Risk Alma Arasındaki İlişkinin Kanonik Korelasyon ile İncelenmesi”, Eğitim Bilimleri Araştırmaları Dergisi, Cilt.3, S.2, (ss.123-146).

KARAKUŞ, Mehmet, (2008), İlköğretim Okul Yöneticilerinin Ve Öğretmenlerin Duygusal Zeka Yeterliklerinin, Öğretmenlerin Duygusal Adanmışlık, Örgütsel Vatandaşlık Ve İş Doyumu Düzeylerine Etkisi, Frat Üniversitesi Sosyal Bilimleri Enstitüsü Yayınlanmamış Doktora Tezi, Elazı̆̆.

KAYGISIZ, Esra, (20013), "Özel Güvenlik Personelinin Örgütsel Vatandaşlık Davranışları”, 3. Ulusal Özel Güvenlik Sempozyumu, 1-2 Mart, Gaziantep, (ss.71-88).

KELLOWAY, E. Kevin, LOUGHLIN, Catherine, BARLING, Julian and NAULT, Alison, (2002), "Self-Reported Counterproductive Behaviors and Organizational Citizenship Behaviors: Separate but Related Constructs”, International Journal of Selection and Assessment, Vol. 10, No. 1/2, (pp.143-151).

KESKİN, S. ve ÖZSOY, A.N. (2004). Kanonik Korelasyon Analizi ve Bir Uygulamas1, Tarım Bilimleri Dergisi, Cilt.10, S.1, (ss. 67-71).

KORKMAZ, Tuğba ve ARPACI, Ebru, (2009), "Relationship of Organizational Citizenship Behavior with Emotional Intelligence", Procedia Social and 
Behavioral Sciences , 1, (pp.2432-2435).

LIEVENS, F., and ANSEEL, F. (2004). "Confirmatory Factor Analysis And Invariance of An Organizational Citizenship Behaviour Measure Across Samples in A Dutch-Speaking Context", Journal of Occupational and Organizational Psychology, Vol.77, (pp.299-306).

MAİNI, Jiwan Jyoti, SİNGH, Bhawdeep and KAUR, Parminder, (2012), "The Relationship among Emotional Intelligence and Outcome Variables: A Study of Indian Employees", Vision, Vol.16, No.3, (pp.187-199).

MAYER, John D., DiPAOLO, Maria and SALOVEY, Peter, (1990), éPerceiving Affective Content in Ambiguous Visual Stimuli: A Component of Emotional Intelligence”, Journal of Personality Assessment, Vol.54, No.3, (pp.772781).

ÖZASLAN, Burcu Özge, ACAR, Aslı ve ACAR, Ahmet Cevat, (2009), "Duygusal Zeka Ve Örgütsel Vatandaslık Davranısı Arasındaki İliskinin İncelenmesine Yönelik Bir Arastırma", Yönetim, Y11.20, S. 64, (ss.98111).

ÖZDEMİR, Y. Aslı ve ÖZDEMİR, Ali.,(2007), "Duygusal Zeka ve Çatışma Yönetimi Stratejileri Arasındaki İlişkilerin İncelenmesi: Üniversitede Çalışan Akademik ve İdari Personel Üzerine Uygulama”, Selçuk Üniversitesi Sosyal Bilimler Enstitüsü Dergisi, Sayı:18, (ss.393-410).

SALOVEY, Peter and MAYER, John D., (1990), "Emotional Intelligence", Imagination, Cognition and Personality, Vol.9, (pp.185-211).

SARI, Çağla, (2011), Örgütsel Adalet Algısının Örgütsel Vatandaşlık Davranışına Etkisi Ve Bir Araştırma, Marmara Üniversitesi Sosyal Bilimler Enstitüsü Yayımlanmamış Yüksek Lisans Tezi, stanbul.

SAYIN, Ayfer, KOĞAR, Hakan ve ÇAKAN, Mehtap, (2012), "Aşamalı Dersler Arasındaki İlişkilerin Kanonik Korelasyon Tekniğiyle İncelenmesi: Sınıf Öğretmenliği Örneği”, Eğitimde ve Psikolojide Ölçme ve Değerlendirme Dergisi, Cilt.3, S.1, (ss.210-220).

SEZGİN, Ferudun, (2005), "Örgütsel Vatandaşlik Davranışları: Kavramsal Bir Çözümleme ve Okul Açısından Bazı Çıkarımlar”, GÜ, Gazi Eğitim Fakültesi Dergisi, Cilt .25, S. 1, (ss.317-339).

SHAFFER, R.D. and SHAFFER M.A. (2005). Emotional intelligence abilities, personality and work place performance, Hong Kong Baptist University Academy of Management Best Conference Paper, HR: M 1

SUDAK, Melike Kıvanç ve ZEHİR, Cemal, (2013), "Kişilik Tipleri, Duygusal Zeka, İş Tatmini İlişkisi Üzerine Yapılan Bir Araştırma”, Yönetim Bilimleri Dergisi, Cilt. 11, S. 22, (ss. 141-165).

TOKMAK, İsmail, YILDIZ, Erkan ve TURGUT, Hakan, (2013), "Duygusal 
Zekanın Örgütsel Vatandaşlık Davranışına Etkisi: İş Tatmininin Aracılık Rolü”, Çağ Üniversitesi Sosyal Bilimler Dergisi, Cilt.10, S.1, (ss.96-115). URAL, Ayhan, (2001), "Yöneticilerde Duygusal Zekanın Üç Boyutu", Dokuz Eylül Üniversitesi Sosyal Bilimler Enstitüsü Dergisi, Cilt 3, Say1:2, (ss.209-219).

WEERDT, Mercedes and ROSSI, Gina (2012), "The Bar-On Emotional Quotient Inventory (EQ-i): Evaluation of Psychometric Aspects in the Dutch Speaking Part of Belgium", http://www.intechopen.com/books. htm (erissim tarihi: 15.10.2014).

WONG, Chi-Sum and LAW, Kenneth S.(2002), "The Effects of Leader And Follower Emotional Intelligence on Performance and Attitude: An Exploratory Study", The Leadership Quarterly, No.13, (pp.243-274).

YILDIRIM, Halil, ALBAYRAK, Ali Sait, GÜMÜŞ, Mustafa ve AKALIN, Tevfik Cem, (2011), "Yüzme Hakemlerinde Örgütsel Bağl1lık İle İş Tatmini Arasındaki İlişkinin Kanonik Korelasyon Analizi İle İncelenmesi”, ZKÜ Sosyal Bilimler Dergisi, Cilt.7, S. 13, ( ss. 163-186).

YÜCEL, Cemil ve SAMANCI, Gülden, (2009), "Örgütsel Güven Ve Örgütsel Vatandaşlık Davranışı, Fırat Üniversitesi Sosyal Bilimler Dergisi, Cilt: 19, Say1: 1, (ss.113-132). 
